\title{
PODCASTS IN TEACHING EFL FOR STUDENTS MAJORING IN ENGINEERING
}

\author{
Olha Chaikovska, Lesia Zbaravska, Tetiana Bilyk \\ State Agrarian and Engineering University in Podillia, Ukraine \\ olgachaikovskaya@ukr.net,olzbaravska@gmail.com,pro-nav@pdatu.edu.ua
}

\begin{abstract}
English proficiency is one of the key factors that influences both the academic life of engineering students and their future career. The application of foreign language teaching podcasts with students of technical universities lacks empirical exploration to support their use. The present paper gives a brief review of scholarly literature published from 2007-2018 on effects of podcasts in foreign language learning that showed that there is not sufficient research on the benefits of using professional podcasts in foreign language study of future engineers. A series of 10 professional engineering podcasts covering "Electrical Engineering" topics were used to improve future engineers' English language competence. The pedagogical experiment has been conducted on the basis of the State Agrarian and Engineering University in Podillia, Ukraine. We collected data from 50 first-year students of the Mechanical and Engineering Department, who were learning English as a foreign language. It is concluded in terms of assessing engineering student performance that the qualitative indicators of students' listening and speaking skills after using professional podcasts are fairly good. This study recommends university teachers to integrate profession-based podcasts with students of technical universities to improve student listening and speaking, to provide participants of the education process with new vocabulary, to encourage the interaction with engineering community and independent student learning outside the classroom.
\end{abstract}

Keywords: EFL, engineering, future job, podcasts, professionally-based.

\section{Introduction}

All language methods and approaches in the history of Pedagogics depended on social services commissioning that influenced the aim, the content and the type of the language. Nowadays, English can be unofficially assumed to be the foreign language number one in Ukraine. It is partly explained by the fact that Ukraine became a member of the EU and, consequently, various programs, internships, education and finance projects Ukrainian students, teaching and scientific staff can participate became frequent. But very often it is challenging to find people in the sphere of engineering, economics, manufacture and education that are fluent in the English language, even if they are experts and authorities in their fields. Without exaggeration, the Ukrainian government and the Ministry of Education of Ukraine took control of the foreign language study. The case is, the percentage of students, who pass the final exam in the English language, increased. For example, in 2018 the percentage of the first year students, who passed an independent final exam in English at schools, was $30 \%$ in comparison with $8.5 \%$ in 2017. The quantitative research was done on the basis of application form analysis of students of the State Agrarian and Engineering University in Podillia majoring inElectrical and Agrarian Engineering. In addition, the general final exam in English was provided at Economic and Law majors to start a Master course in Ukraine. Next year the final exam in English will be obligatory for students of engineering specialties. Moreover, a job of an engineer in Ukraine takes the $5^{\text {th }}$ place in the list of jobs, where foreign language competence influences occupational prestige and the rate of wages. In accordance with the above, it is understood that the quality of foreign language instruction is an up-to-date issue. That is why foreign language teachers should adopt different techniques and approaches to teaching a foreign language. Some of them turn out to be successful, others are not effective and do not give the expected results in short periods of time. Nowadays, social media technologies, potential of comics, webinars and on-line courses are used to make learning the foreign language both effective and interesting. It is not a secret that modern teenagers are at ease with state-of-the-art technologies. Besides, we live in the era, where all kinds of activities have the tendency to be simplified. Nowadays, people all over the world try to do the best of their time and not to lose a minute. And what is more, to make less effort to get good results. As far as podcasts are concerned you can listen to the information you need while commuting to work or study, driving a car, walking in the park and doing routine work. Scientists proved that brain works better while person is walking, so you have an opportunity to remember new words and phrases and to practice your listening. The teaching method we would like to focus in our study meets the main requirements of modern society and, to our point of view, can compete with traditional and effective teaching strategies. Another important issue is that podcasts are not frequently used, and what more, 
are unfamiliar to both teachers and students. We consider that educational podcasts are one of the useful and time-saving learning tools for developing listening and speaking skills.

Listening comprehension is one of the most difficult tasks for EFL (English Foreign Language) students. Recently podcasts generated a lot of interest due to their ability to be integrated in studying to improve student listening, speaking and reading skills. The review of the literature on podcasts showed that foreign academics were pioneers in implementation of innovative teaching tools. They claim that podcasts provide positive students' attitude towards learning [1-3], behavior and selfefficacy[4]; this innovative mobile technology may offer a rich input through authentic speech [5] and raise language awareness, allow learners to carry out homework assignments at their own pace and under non-threatening conditions [6]. Some scientists designed pedagogical models for podcasts in higher education [7], created podcasts that can be implemented in teaching English [8], studied podcasts as a new technological tool in higher education [9-12], the effectiveness of M-learning in the form of podcast revision lectures in higher education [13]. As we see, the majority of studies regarded the practice of podcast use in foreign language teaching context both in schools and universities. Initial investigation indicated that there is a lack of researches that focus on the effects of podcasts in teaching English for students of engineering specialties. The aim of the present study was to investigate the characteristics of the classical teaching methods, adopt podcasts to create the procedure for podcast-based tasks. We have examined more than 20 podcast resources to select the ones that offer interesting tips for engineering students to enhance their listening and speaking in professional sphere. This study intended to integrate podcasts into teaching EFL for students of the Engineering Department to explore the impact of podcasts on learners' listening and speaking skills in Ukrainian context.

\section{Research methods}

The research was carried out on the basis of the State Agrarian and Engineering University in Podillia. The pedagogical experiment involved 50 first-year students of the Mechanical and Engineering Department, majoring in "Electrical Engineering". In order to achieve the objective of this study, the authors of the study designed a questionnaire and a quasi-experiment using pre-test and post-test. Both tests had a similar format and were focused on listening comprehension and speaking. Students of the control (24 students) and the experimental (26 students) groups have finished technical and agrarian colleges from nearby regions. According to the university curriculum the students study "English for professional purpose" during the first semester at our university (15 weeks, one period a week). What is important, the division of hours for classwork and self-study was 1 to 2 , which is 30 hours of class activities and 60 hours of self-study. The control and the experimental group had the same number of EFL classes. Podcasts were used only with the experimental group.

\section{Results and discussion}

Podcasts as a technique for studying a foreign language have their roots in the natural language learning method, which is considered to be the oldest one. A foreign language was studied on the basis of imitation and frequent repetition of ready speech samples.

We cannot deny the fact that podcasts have much in common with the oral method of Palmer, which later had an impact on audio-lingual and audio-visual methods. According to Palmer the main principles of foreign language study are imitation and learning by heart. A method that employed no mediation of the mother tongue took ground. "In this case, as the mother tongue was completely excluded from teaching, no translation was used"[14]. The emphasis in Palmer's works is on teaching of the spoken language, which is based on everyday speech of ordinary people. Learning to speak a foreign language by using what Palmer called spontaneous language acquisition capacities is very close to the idea of podcasts. Podcasts can be used as a context while doing other activities, so if you have no desire or opportunity to read the text that accompanies the speech, you may just listen to the chosen topics. In podcasts we deal with authentic texts. This is an opportunity to explore how English is really used by native speakers. Authentic texts should be used in EFL lessons to give the students more of a sense how English is really used.

Naturally, podcasts are texts read by one native speaker or dialogues, interviews between several persons. It is obvious that they are aimed at training listening and speaking skills through frequent 
listening, remembering and repetition. Some academics argue that a foreign language teacher, who wants to apply audio-lingual method, should be a native speaker to give proper speech patterns for imitation. Podcasts are more universal language study tools and a foreign language teacher, who is not a native speaker, can use them in EFL classroom. They can be used both in self-study and at EFL classes. In the first case, the level of self-motivation and discipline of the student should be very high. The students can easily download podcasts and receive new episodes every week. The topics themselves are very interesting: "Whose game is it?" (the podcast describes the changes that took place in football game), "New Year's revolution" (the listener will know about the traditions of celebrating New Year in Scotland), the podcast "The Iron Lady" is devoted to Margaret Thatcher and tells the story how she became the "Iron Lady", in the episode "Backseat drivers" the students will hear about the British love of driving from classic to Formula 1 racing, about great British cheeses, about British love of books. The students will be able to find out how tea was making a comeback to the UK, how the biggest names in British music were created. But listening to podcasts only for one time and having no learning strategies will, unfortunately, lead to poor results. In the other case, podcasts can be used as the possible teaching tools. And it depends only on a teacher, who has to create the procedure for podcast usage.

During the experiment our task was to find podcasts that correspond to general and professional topics. As the questionnaire showed, $10 \%$ of the first-year students have heard about podcasts, $2 \%$ of the respondents knew that they can be used in EFL learning, but had no experience of listening to podcasts. The authors of the paper have examined the following podcast resources: "This American Life" (episodes have a similar format to radio programme), "The English we speak" (BBC podcasts focused on everyday phrases, idioms and slang with a bit slower speaking speed than in usual life), "English class 101 by innovative language" (presentation of culturally relevant information, definitions of the words and phrases and even grammar), "British Council Podcasts". The procedure of studying English on the basis of podcasts in class can differ according to the language level of the listeners. What is important, students need time to learn how to read, listen and watch, and take notes on podcasts. The teacher should realize that most students may have never been engaged with podcasts. Firstly, we think that reading "details" of podcasts in advance is very helpful. Moreover, advanced students can find additional information on the topic; while weaker students can practice new vocabulary (we prepared the lists of words and phrases beforehand). During our experiment we used both audio podcasts and video podcasts. For the beginning we have chosen Professionals Podcasts series from the British Council: episode 1 (a journalist is giving advice on interviewing techniques; time 3 min.), episode 2 (an interview with a recruitment expert, who talks about his experience of reading CVs and offers some good advice on writing them; time: 4 min.). The first episode is a monolog and the second one is presented in a form of a dialogue. After listening to the text the teacher should diagnose the level of student understanding. The teacher can develop a set of training exercises: true or false, multiple choices, open-ended questions, put the paragraphs/questions into correct order, complete the sentences about the text, missing words. We found it very useful to pause each passage and ask the students to repeat after the reader. One of the student favorite activities is the role play or act-it-out. Episodes with interviews are very good for role plays. At home students listen to the same podcast and act-it-out, which is good both for beginners and advanced students. Moreover, advanced students can create podcasts themselves. But before that the teacher has to show the tools for recording a podcast, interviewing people, adding music, combining the slides and etc.

We could not ignore the fact that we teach students of technical specialties, so we also analyzed professional podcasts that cover topics for young engineers, apprentices, students and engineering graduates: "Successful Farming" (a kind of on-line magazine, where you can hear up-to-date news from experts and leaders in the agricultural industry), "Talking Machines", "TED talks". The approximate time of professional Engineering podcasts is 20 minutes (some advanced podcasts last 45 minutes), so it will be rather difficult for EFL students to master profession based topics. We came to a conclusion that "TED talks" podcasts will be the most convenient ones. This time our experimental group worked with video podcasts. It should be noted that not all of them cover engineering topics. But one of the advantages is the comparatively short time of each episode (10 minutes).For students of the Engineering and Technical Department we have chosen the following topics: "What should electric cars sound like?" (12 min.), "The four things you need to know about the 
energy you use" (14 min.), "100 solutions to reverse global warming" (17 min.), "How machine learning can teach us to build more effective teams" (9 min.), "Why machines must make us better humans" (13 min.), "A local sustainable solution to the energy crisis" ( $8 \mathrm{~min}$.). The following podcasts were employed in ESL classroom on the basis of pre-watching and post-watching activities. Before watching the podcasts the students were asked to analyze the "details" of the future podcast. As a rule the "details" contain brief information on the topic and some thought provocative questions (e.g. What kind of sounds should electric cars make to keep people safe?), to find additional information on electric cars. (When and where were invented? What are the advantages and disadvantages?), to look through the list of words that are going to have in the episode (What words are familiar to you? Choose the best variant to remember unknown words (word maps, flashcards with Quizlet, AnkiDroid flashcards)).

As far as professional Engineering podcasts are concerned, we divided the episode into fragments. It is easier to discuss unknown words and phrases, difficult grammar constructions within small fragments. During the experiment we did not forget to pause the video and repeat both the words and the sentences, because most of the students have difficulties with correct pronunciation, word stress and intonation of interrogative and exclamatory sentences. With the help of podcasts we learnt how to provide meaning through emphasis. What is important, new English vocabulary should be revised constantly. So, we had different kinds of tests, quizzes and dictations on the previous video vocabulary. After having watched the professional engineering podcasts the students were given questionnaires filled with questions related to the video, Who? Where? Why? How? charts, where students wrote the basic facts under each question word; exercises on matching names, numbers, tasks on interpreting gestures and mimics of the speaker. Advanced students could read more about the EU regulations on the sound level of motor vehicles and of replacement silencing systems and, for instance, the National Highway Traffic Safety Administration's minimum sound requirements for hybrid and electric vehicles at home. The full texts are given in the "reading list" section. We would recommend enhancing the students to make comments on podcasts. This could be one of the most interesting and effective activities for EFL students. First of all, it is about getting interesting information and learning from native English speakers to sound more natural. Secondly, students became part of community that is fond of engineering and got new pen pals.

The students of the control group studied English with General English guide for students of engineering specialties, while the students of the experimental group had English classes with podcast integration. The final test that comprised listening comprehension and speaking was given to students of both groups. The comparative results are given in Table 1 .

Comparative results of pre-experimental and post-experimental testing

\begin{tabular}{|c|c|c|c|c|c|}
\hline \multirow{2}{*}{$\begin{array}{c}\text { English } \\
\text { language } \\
\text { competence }\end{array}$} & Grade & $\begin{array}{c}\text { Experimental } \\
\text { group } \\
\text { (26 students) }\end{array}$ & $\begin{array}{c}\text { Control } \\
\text { group } \\
\text { (24 students) }\end{array}$ & $\begin{array}{c}\text { Experimental } \\
\text { group } \\
(26 \text { students) }\end{array}$ & $\begin{array}{c}\text { Control } \\
\text { group } \\
(24 \text { students) }\end{array}$ \\
\hline \multirow{4}{*}{$\begin{array}{c}\text { Listening } \\
\text { comprehension }\end{array}$} & $\mathrm{A}$ & - & - & $2 / 7.7 \%$ & - \\
\cline { 2 - 6 } & $\mathrm{B}$ & $4 / 15.4 \%$ & $6 / 25 \%$ & $8 / 30.7 \%$ & $6 / 25 \%$ \\
\cline { 2 - 6 } & $\mathrm{C}$ & $10 / 38.4 \%$ & $6 / 25 \%$ & $10 / 38.4 \%$ & $8 / 33.3 \%$ \\
\cline { 2 - 6 } & $\mathrm{D}$ & $6 / 23.1 \%$ & $4 / 16.7 \%$ & $4 / 15.4 \%$ & $4 / 16.7 \%$ \\
\cline { 2 - 6 } & $\mathrm{E}$ & $6 / 23.1 \%$ & $8 / 33.3 \%$ & $2 / 7.7 \%$ & $6 / 25 \%$ \\
\hline \multirow{4}{*}{ Speaking } & $\mathrm{A}$ & $2 / 7.7 \%$ & $2 / 8.3 \%$ & $4 / 15.4 \%$ & $2 / 8.3 \%$ \\
\cline { 2 - 6 } & $\mathrm{B}$ & $4 / 15.4 \%$ & $4 / 16.7 \%$ & $8 / 30.7 \%$ & $4 / 16.7 \%$ \\
\cline { 2 - 6 } & $\mathrm{C}$ & $6 / 23.1 \%$ & $6 / 25 \%$ & $8 / 30.7 \%$ & $6 / 25 \%$ \\
\cline { 2 - 6 } & $\mathrm{D}$ & $8 / 30.7 \%$ & $6 / 25 \%$ & $4 / 15.4 \%$ & $10 / 33.3 \%$ \\
\cline { 2 - 6 } & $\mathrm{E}$ & $6 / 23.1 \%$ & $4 / 25 \%$ & $2 / 7.7 \%$ & $2 / 8.3 \%$ \\
\hline
\end{tabular}

The result of this study revealed that the post-test scores were better than the pre-test scores of the experimental group. It could be seen by comparing their means. The qualitative indicator of preexperiment and post-experiment testing in listening comprehension increased from $54 \%$ to $77 \%$. There is a growth from $46.2 \%$ to $69 \%$ in speaking. As far as the control group is concerned the 
means of qualitative indicators are as follows: from $50 \%$ to $58 \%$ (listening comprehension) and the qualitative indicators in speaking are the same. 10 students of 26 in the experimental group raised their grades in comparison to 4 out of 24 students in the control group. The same results can be observed in the speaking section of post-experiment testing. We came to a conclusion that the coefficients could be higher, if the term of EFL study was longer, at least one semester. But still the difference in grade of the testing achieved by the students after they have been taught to use podcasts in classroom and at home proved the effectiveness of integration podcasts in teaching EFL for engineering specialties.

\section{Conclusions}

To sum up, English is taught in Ukraine as a foreign language. Although our country has significant achievements in the field of education, the level of EFL learning is still insufficient, especially in the context of technical high schools. English competence of a future engineer is the ability to work in a foreign company, to quickly get promoted at work, to go on business trips and to get a big salary. So, most academics claimed that teachers should implement innovative technologies in foreign language teaching practice. One of the effective language teaching instruments is podcasting. To make podcasts work the teacher should create a system of podcast-based tasks taking into account the characteristics that are common to the oral method of Palmer and the audio-lingual method. It means that it should be based on constant repetition and imitation of speech patterns. The focus of our research was to explore the effect of podcasts on engineering students' listening comprehension and speaking. The results of the survey showed that the students of the experimental group achieved better listening comprehension and speaking performance than the students of the control group. The participants of the experiment showed positive attitude towards engineering podcasts, they stated that this technology enhances conversational skills in the professional field, improves comprehension, improves pronunciation and dialect, fosters social engagement and motivates for self-studying. We would recommend incorporating professional podcasts in EFL teaching for the students of technical universities. Further studies are required to explore the effects of podcasts in EFL learning with the full-time and part-time students major in transport technology, agrarian engineering, and agronomy.

\section{References}

[1] Chan M., Chi W., Chin N. etc. Students' perceptions of and attitudes towards podcast-based learning: A comparison of two language podcast projects. Electronic Journal of Foreign Language Teaching, vol. 8(1), 2011, pp. 312-335.

[2] Fernandez V., Simo P., Sallan J. M. Podcasting: A new technological tool to facilitate good practice in higher education. Computers \& Education, vol. 53(2), pp. 385-392.

[3] E. M., Bowles A. R., Frank V. M. etc. (2014). Technologies for foreign language learning: A review of technology types and their effectiveness. Computer Assisted Language Learning, vol. 27(1), 2014, pp. 70-105.

[4] Kavaliauskienė G., Anusienė L. English for specific purposes: Podcasts for listening skills. Coactivity: Philology, Educology, vol.17(2), 2009, pp. 28-37.

[5] Edirisingha P., Salmon, G. Pedagogical models for podcasts in higher education, 2007. [online] [06.10.2018]. Available at:http://hdl.handle.net/2381/405.

[6] Istanto J. W. PelangiBahasa Indonesia podcast: what, why and how? Electronic Journal of Foreign Language Teaching, vol. 8(1), 2011, pp. 371-384.

[7] Al-Qasim N., Al-Fadda H. From Call to Mall: The Effectiveness of Podcast on EFL Higher Education Students' Listening Comprehension. English Language Teaching, vol. 6(9), 2013, pp. 22-30.

[8] Hrytsyk N.V. Podcasting technology in teaching a foreign language (according to professional direction). Journal of Chernihiv national pedagogical University. Series: Pedagogical Sciences, vol.124, 2015,pp. 24-26.

[9] Drobit I.Use of podcasts while teaching English language according to professional direction. Journal of Lviv state University of life safety, vol. 5 (2), 2011, pp. 89-92. 
[10]Chaikovska O. Podcasts in teaching ESL. Scientific Herald of the Institute of Vocational Education and Training of the National Academy of Pedagogical Sciences, vol.16, 2018, pp. 142-146.

[11]Evans, C. The Effectiveness of M-Learning in the form of podcast revision lectures in higher education. Computers \& Education, vol. 50(2), 2008, pp. 491-498.

[12] Kardashova N. V. English podcast as a means of forming competence in listening to students of language specialties. Journal of Kyiv National Linguistic University. Series: Pedagogics and Psychology, vol.24, 2015, pp. 176-185.

[13] Rosell-Aguilar F. Top of the pods-In search of a podcasting "Podagogy" for language learning. Computer Assisted Language Learning, vol. 20(5), 2007, pp. 471-492.

[14] Tamura E. Concepts on the Methodology of Teaching English. The Economic Journal of Takasaki City University of Economics, vol. 48 (3), 2006, pp. 169-188. 